\title{
A survey on zoo mortality over a 12-year period in Italy
}

\author{
Frine Eleonora Scaglione ${ }^{\text {Corresp., }}{ }^{1}$, Angelica Ferro ${ }^{1}$, Paola Pregel ${ }^{1}$, Enrica Berio ${ }^{1}$, Francesca Tiziana Cannizzo \\ ${ }^{1}$, Bartolomeo Biolatti ${ }^{1}$, Enrico Bollo ${ }^{1}$ \\ ${ }^{1}$ Department of Veterinary Science, University of Turin, Grugliasco, Italy \\ Corresponding Author: Frine Eleonora Scaglione \\ Email address: frineeleonora.scaglione@unito.it
}

Background. The zoo is a unique environment in which to study animals. Zoos have a long history of research into aspects of animal biology, even if this was not the primary purpose for which they were established. The data collected from zoo animals can have a great biological relevance and it can tell us more about what these animals are like outside the captive environment. In order to ensure the health of all captive animals, it is important to perform a post-mortem examination on all the animals that die in captivity. Methods. The causes of mortality of two hundred and eighty two mammals which died between 2004 and 2015 in three different Italian zoos (a Biopark, a Safari Park and a private conservation center) have been investigated. Results. Post mortem findings have been evaluated reporting the cause of death, zoo type, year and animal category. The animals frequently died from infectious diseases, in particular the causes of death in ruminants were mostly related to gastro-intestinal pathologies. pulmonary diseases were also very common in each of the zoos in the study. Moreover, death was sometimes attributable to traumas, as a result of fighting between conspecifics or during mating. Cases of genetic diseases and malformations have also been registered. Discussion. This research was a confirmation of how conservation, histology and pathology are all connected through individual animals. These areas of expertise are extremely important to ensure the survival of rare and endangered species and to learn more about their morphological and physiological conditions. They are also useful to control pathologies, parasites and illnesses that can have a great impact on the species in captivity. Finally, this study underlines the importance of a close collaboration between veterinarians, zoo biologists and pathologists. Necropsy findings can help conservationists to determine how to support wild animal populations. 


\section{A survey on zoo mortality over a 12-year period in Italy}

2 Frine Eleonora Scaglione *, Angelica Ferro *, Paola Pregel *, Enrica Berio *, Francesca Tiziana

3 Cannizzo *, Bartolomeo Biolatti *, Enrico Bollo *

4

5 *University of Turin, Department of Veterinary Science, Largo P. Braccini 2, 10095 Grugliasco (To),

$6 \quad$ Italy

7

8

9 Corresponding author:

10 Frine Eleonora Scaglione

11 e-mail: frineeleonora.scaglione@unito.it 
23 Abstract

24 Background. The zoo is a unique environment in which to study animals. Zoos have a long history of research into aspects of animal biology, even if this was not the primary purpose for which they were established. The data collected from zoo animals can have a great biological relevance and it can tell us more about what these animals are like outside the captive environment. In order to ensure the health of all captive animals, it is important to perform a post-mortem examination on all the animals that die in captivity.

Methods. The causes of mortality of two hundred and eighty two mammals which died between 2004 and 2015 in three different Italian zoos (a Biopark, a Safari Park and a private conservation center) have been investigated.

33 Results. Post mortem findings have been evaluated reporting the cause of death, zoo type, year and animal category. The animals frequently died from infectious diseases, in particular the causes of death in ruminants were mostly related to gastro-intestinal pathologies. pulmonary diseases were also very common in each of the zoos in the study. Moreover, death was sometimes attributable to traumas, as a result of fighting between conspecifics or during mating. Cases of genetic diseases and malformations have also been registered.

Discussion. This research was a confirmation of how conservation, histology and pathology are all connected through individual animals. These areas of expertise are extremely important to ensure the survival of rare and endangered species and to learn more about their morphological and physiological conditions. They are also useful to control pathologies, parasites and illnesses that can have a great impact on the species in captivity. 
44 Finally, this study underlines the importance of a close collaboration between veterinarians, zoo 45 biologists and pathologists.

46 Necropsy findings can help conservationists to determine how to support wild animal populations.

47

48

\section{INTRODUCTION}

Zoos have always been considered as establishments where wild animals are kept for exhibition (other than a circus or a pet shop) to which members of the public have access, with or without charge for admission, for a minimum period of seven calendar days per year (Hosey et al., 2009). Many zoos around the world keep animals confined to small spaces compared to their wide-ranging peers in the wild. Due to spatial constraints captive environments have difficulty in providing the ideal setting for natural behaviour, such as hunting, resulting in welfare issues among captive animals (Morgan and Tromborg, 2007). Sometimes, animals in captivity exhibit abnormal behaviour such stereotypies (Vaz et al., 2017) or aggressiveness (Salas et al., 2016) due to poor welfare, as behaviour is an animal's "first line of defence" in response to environmental change, i.e., what animals do to interact with, respond to, and control their environment (Mench, 1998). Moreover, in literature, the pathologies affecting captive animals have been shown to be different from the ones affecting wild populations (Seeley et al., 2016; Strong et al., 2016).

Fortunately today, the concept of zoo has changed. Many associations cooperate together to give a new point of view about zoos. It is important to highlight that zoos are not simply cages in which animals are kept prisoner, as many people believe. They should be valued for their aims and goals. One of the key goals of many captive management programs is the eventual reintroduction of species back into the wild. Zoos exhibit species to educate the public and cultivate its appreciation of conservation or research programs. Zoos offer their visitors "edu-trainment" through shows, contact areas, and 
67 interactive exhibits. They also begin to reflect on the reason for their existence, along with issues

68 related to animal welfare, such as behavior, exhibit design, and nutrition (Griffin et al., 1992).

69 There are many types of modern zoos: safari parks, conservation centers, landscape immersions, 70 ecosystem exhibits, as well as bioparks and sustainable zoos. Research, education and conservation are

71 functions which, in the last one hundred years or so, have been grafted onto the recreational rootstock 72 of zoos (Robinson, 1989).

73 Keeping wild animals in captivity has advantages, first of all, for animals (conservation can be viewed 74 as beneficial for populations of animals, if not always for individual animals kept in captivity) and for 75 humans as well (education, conservation, recreation and scientific discovery). Wild animals in captivity may not necessarily experience negative welfare and may, in some cases, be better off than

77 they would be in the wild (Bostock, 1993).

78 Conservation of endangered species is now one of the major goals of accredited zoos. The emphasis on 79 a conservation role for zoos grew greatly in importance during the 1970s and 1980s, prompted partly 80 by the zoos themselves and partly by external pressures, such as new international treaties and national 81 legislation (Hosey et al., 2009). Another important aspect related to conservation is biodiversity.

82 Today, the term "conservation" and "biodiversity" are often used together, to make explicit the 83 distinction between the conservation of living organism and non-living structures, such as buildings or 84 books (Hosey et al., 2009). Another way of defining biodiversity would be as the sum total of genes, 85 species and ecosystem in a region (WRI/IUCN/UNEP/FAO/UNESCO, 1992). The role of the zoo in 86 the conservation of biodiversity can be defined in four general areas:

87 -maintenance of captive stocks of endangered species; this is the idea of zoo that can act as a kind of 88 'ark'; 
89

90

91

92

93

94

95

96

97

98

99

100

101

102

103

104

105

106

107

108

109

110

111

-support for, and practical involvement with, in situ conservation projects. Zoos could contribute to this with, amongst other things, animal planning expertise, infrastructure, and financial support;

•education and campaigning about conservation issues; this can be achieved through enclosure design, signage, keeper talks, interactive education, animal shows... Indeed, it is as important sometimes to keep species of low conservation importance in zoos as it is to keep the high-priority species, because they may be more useful in promoting the conservation message by enhancing people's experience of animals at the zoo;

-research that benefits the science and practice of conservation; for many years, research conducted on zoo animals tended to be concerned primarily with anatomy and taxonomy, but there is a huge potential in zoo to undertake behavioral, genetic, and physiological research that contributes to the in situ and ex situ conservation of endangered species (Ryder and Feistner, 1995).

These roles and activities have been pointed out in three documents: "The World Zoo Conservation Strategy" (IUDZG/CBSG, 1993), "The World Zoo and Aquarium Conservation Strategy" (WAZA, 2005) and "Turning the Tide" (Hosey et al., 2009; WAZA, 2009).

The zoo is a unique environment in which to study animals. Unlike in the wild, the animals are easily accessible to the researcher, so within the framework of structured research and with the correct licenses, data from zoo animals can be collected which would otherwise be very difficult to get from their wild counterparts from a logistical point of view. Furthermore, unlike in the wild, some manipulations may be possible in the zoo to take research beyond the purely observational and into experimental approaches (Hosey et al., 2009), even if some data might be biased by captivity (i.e. behavior, hunting).

Zoos have a long history of research into aspects of animal biology, even if this was not the primary purpose for which they were established (Hutchins, 2001). 
112 The data collected from zoo animals can have a greater biological relevance than data obtained from

113 the laboratory, and it can tell us more about what these animals are like outside the captive

114 environment (Hosey et al., 2009).

115 As a consequence, many zoos carry out their research in collaboration both with other zoos and with

116 other bodies, such as universities and conservation agencies. Indeed, universities and zoos can

117 complement each other, for example on topics such as the control and analysis of behavior,

118 conservation of endangered species, the education of students and the general public (Fernandez and

119 Timberlake, 2008). One of the greatest examples of the importance of research in zoo animals is the

120 discovery and management of diseases.

121 Diseases may be 'of concern' to zoos either because of the direct risk of animal loss or because of the

122 impact on the zoo of required measures in the case of an outbreak.

123 Each zoo will have different 'diseases of concern', depending on its geographical location and the

124 types of animal in its collection, which may vary quite widely from collection to collection, and over 125 time.

126 Diseases can be considered under four broad headings for all zoos:

127 - infectious diseases;

128 -degenerative diseases;

129 -genetic diseases;

$130 \bullet$ nutritional diseases (Hoseyet al., 2009).

131 Furthermore capture, restraint, and anesthesia are also stressful procedures for animals, and 132 particularly so for wild species. It may be better to leave an animal with a superficial injury to heal on 133 its own without treatment if the only alternative is capture and full anesthesia. Veterinary treatment 134 may have adverse effects on an animal's reproductive status, or may result in aggression from 
135 conspecifics when an individual is removed for treatment and then returned into a social group.

136 Medication that can be administered in food or drinking water may be an option when capture and

137 injection of drug is not desirable from a welfare perspective, or when it would put veterinary staff or

138 keepers at high risk of injury. Euthanasia is also an option (Hoseyet al., 2009).

139 Preventive medicine and care play a very important role in zoos. The preventive medicine program for 140 captive wild animals includes: stock selection, quarantine, routine health monitoring and maintenance, 141 enclosure design, pest control, sanitation, and an employee health program. The overall goals of a 142 preventive medicine program are to prevent disease from entering the animal collection, to ensure that 143 the animals are properly maintained, and to avoid dissemination of diseases to other institutions, or to 144 free-ranging populations if collection animals belong to a reintroduction program (Norton, 1993).

145 Preventive medicine often starts with the careful selection of new animals and a period of quarantine 146 or isolation.

147 In order to protect the health of all captive animals, it is important to perform a post-mortem 148 examination on all the animals that die in the collection and also on wild and feral animals found dead 149 on the zoo grounds (Hosey et al., 2009). Many Species Survival Plans (SSPs) have extensive necropsy 150 protocols, so the appropriate SSP Veterinary Advisor should be consulted in advance for this 151 information (Silberman, 1988).

152 Proper disposal of animal carcasses is essential for both human and animal health, as well as to comply 153 with local and federal regulations (Hinshaw et al., 1996).

154 Long-term post-mortem records provide useful data on trends in health, both for individual zoos and 155 among the wider zoo community, and this information can then help future decisions about health care 156 in living animals. 
157 The aim of the study was to evaluate the mortality causes, to highlight the importance of post-mortem 158 examination and its role in preventive medicine and, secondly, to consider the importance of the 159 veterinarian collaboration and cooperation between zoological gardens.

160 There are potential criticisms to this paper. Due to privacy policies, there is a lack of data regarding the 161 animal inventory in relation to the number of necropsies. The authors are not allowed to report the data 162 regarding the number of new animals arriving in the zoo, the number of births, the number of animals 163 sent to other zoos, and this all influences the number of dead animals.

\section{MATERIALS AND METHODS}

\section{Sample Collection}

166 The study on the causes of death in zoo animals was performed taking into account the years from 1672004 and 2015. It was decided to focus on the Order of mammalians only, which has been divided into 168 four categories: monogastric herbivores, ruminants, carnivores and omnivores. Two hundred and 169 eighty two necropsies were carried out.

170 The animals came from three different Italian zoos (a Biopark, a Safari Park and a private conservation 171 center) and were referred to the Department of Veterinary Science of the University of Turin (Italy).

172 Sample analysis

173 Necropsy examination was performed for each animal by two pathologists. A file was filled in with the

174 following fields: assigned number, autopsy date, zoo of origin, species, sex, age, sampled organs.

175 Gross examinations were performed for each animal. Based on the macroscopic findings, the 176 pathologists sampled organs for the histological and/or microbiological investigations.

177 The organs were fixed in 10\% neutral buffered formalin for histological examination. The samples 178 were paraffin-embedded and sections of $4 \mu \mathrm{m}$ were stained with hematoxylin and eosin. Histochemical 179 or immunohistochemical staining was performed, if necessary. All possible differential diagnoses were 
180 taken into account. Bacteriological, virological and parasitological investigations were performed, if 181 needed.

182 Macroscopical and/or microscopic findings were classified according to the cause of death, including 183 spontaneous pathology, infectious, genetic, complications (e.g. anesthesiological and surgical 184 problems, management) and other causes (e.g.: degenerative, neoplasia, nutritional and not determined 185 diseases).

186 Statistical Analysis

187 The resulting data were analyzed by GraphPad Prism (vers. 6.0; GraphPad Software, California, USA).

188 The association between the different tested variables was assessed by $\chi 2$ Test. All results were 189 considered statistically significant with the value $\mathrm{p}<0.05$.

\section{RESULTS}

192 In Table 1 and Figure 1, the total number of dead animals and their causes of death in the three 193 different zoos is summarized.

194 Animals were classified according to their digestive system, with reference to the three zoos. Out of 195 the 282 dead animals, 45 were monogastric herbivores, 175 were ruminants, 54 carnivores, and 8 of 196 them were omnivores.

197 A statistically significant association $(\mathrm{P}<0.01)$ between the zoo and the category of animals was 198 detected.

199 Animals were analyzed separately according to the provenance from the various zoos, and they were 200 classified on the basis of their digestive system and the cause of death. A statistically significant 201 association has been revealed between the category of dead animals and the three zoos $(\mathrm{p}<0.0001)$.

202 Moreover, when the zoos were considered together, a statistically significant association was also 203 revealed between the category of dead animals and the cause of death $(p<0.0001)$. 
204 In Zoo 1 out of the 60 dead animals, 25 (41.7\%) were monogastric herbivores and 19 (76\%) of them 205 died from infectious diseases. Out of 31 (51.7\%) ruminants, 22 (71\%) died from infectious diseases. In 206 Zoo 2, out of 162 dead animals, 105 (64.8\%) were ruminants, and 75 (71.4\%) died from infectious 207 diseases, as well as $14(29.2 \%)$ of the $48(29.6 \%)$ carnivores. Fifteen $(31.2 \%)$ carnivores died from 208 genetic diseases or malformations and 5 (10.4\%) from complications. In Zoo 3, of 60 dead animals, 30 $209(76.9 \%)$ of the $39(65 \%)$ ruminants and $11(73.3 \%)$ of the $15(25 \%)$ monogastric herbivores died from 210 infectious diseases.

211 In Zoo 1, the highest level of mortality was found in 2013, when 15 animals died (25\%) and of them, $21212(80 \%)$ died from infectious diseases.

213 In 2015, 12 deaths were registered (20\%) and of these $10(83.3 \%)$ were from infectious diseases. Out 214 of the 15 animals which died in 2013 in Zoo 1, 7 (46.7\%) were monogastric herbivores and 7 (46.7\%) 215 were ruminants (Table 2).

216 In 2015, out of the 12 deaths registered, 5 (41.7\%) were represented by monogastric herbivores and 7 $217(58.3 \%)$ by ruminants. In Zoo 2 mortality was particularly high in 2009, with 32 (19.7\%) deaths, 25 of 218 which (78.1\%) from infectious disease.

219 The most significant years for mortality in Zoo 2 were from 2006 to 2010, and involved mostly 220 carnivores and ruminants (Table 3 ).

221 The highest mortality in Zoo 3 was in 2004, with 39 (65\%) deaths.

222 Among them, 29 (74.3\%) died from infectious disease. In 200519 (31.7\%) deaths were registered and $22312(63.1 \%)$ of them were attributable to infectious diseases.

224 In Zoo 3 in 2004, out of the $39(65 \%)$ dead animals, $29(74.3 \%)$ were ruminants and $7(17.9 \%)$ were 225 monogastric herbivores. In 2005, of 19 (31.7\%) dead animals 10 (52.6\%) were ruminants, 7 (36.8\%) 226 were monogastric herbivores, and 2 (10.5\%) carnivores (Table 4). 
227 Neoplasia, degenerative, nutritional and not determined diseases were classified as "other" in all the

228 zoos, since some pathologies were not clearly ascribable to a specific cause (e.g.: when hepatic failure

229 occurred as a result of steatosis the primary cause of this disease could be attributable both to

230 degenerative or a nutritional factor)

231

232

233 Post-mortem Findings in Zoos

234 The results obtained from laboratory investigations performed on animal death in the three zoos are 235 reported in Tables 5-7.

236 DISCUSSION

237 After the death of an animal, zoos are always advised to perform post-mortem examinations. The 238 responsibility for this decision normally lies with the zoo veterinarian. Fast retrieval, storage and 239 disposal of the carcass, contact with a specialized pathologist and record keeping are good practices to 240 facilitate the high quality of post-mortem examinations. The safety of the staff in contact with dead 241 animals is also relevant for inclusion in the protocol for post-mortem procedures (EU. Zoo Directive. 242 2015).

243 The cause of death for each animal dying in the collection needs to be established where reasonable 244 and practicable to do so, including, in the majority of cases, the examination of the specimen by a 245 veterinary surgeon, pathologist or practitioner with relevant experience and training (EAZA, 2014).

246 Often parasites, nutritional deficiencies, or dental disease, may be present in the animal collection 247 without causing any obvious symptoms or clinical signs. Their detection at post-mortem examination 248 frequently indicates that diagnostic tests or treatments should be performed on the remaining animals 249 before clinical symptoms or disease transmission occur (Defra, 2012). 
250 In this survey a general analysis has been reported, conducted by a group of veterinary pathologists, on

251 the most common causes of death in zoo animals, over a twelve-year period. In order to provide

252 complete and satisfactory data, 282 necropsies of zoo animals were performed.

253 Three different types of zoo were included in the study (a Biopark, a Safari Park and a private 254 conservation center) as each of these zoos had a different approach to the idea of zoo animal 255 husbandry, as described in the introduction.

256 Interesting considerations can be made, on the basis of the obtained results.

257 Depending on the type of zoo, the category of dead animals and causes of death were represented 258 differently, probably due to the diverse management system of enclosures used.

259 Trauma can occur as a result of poor enclosure design or during capture and transport. Moreover, 260 animals may also be injured in fights with conspecifics, particularly after introduction into a new social 261 group, or during mating. In fact forty seven animals $(16.7 \%)$ of the study died from trauma due to 262 injuries by conspecifics or capture.

263 Zoo animals are protected from some health risks that are normally faced by wild animals, thanks to 264 measures such as vaccination (Fernández-Bellon et al., 2017) and the provision of an adequate diet. At 265 the same time, contracting an illness remains an inevitable part of zoo animal life. In fact, diseases may 266 be spread to zoo animals through contact with conspecifics, free-ranging species, pests, such as rats 267 and mice, keepers or visitors (Schaftenaar, 2002; Zhang et al., 2017). The study highlights that the 268 main cause of death of captive mammals, was attributed to infectious disease (177 animals, 62.8\%). 269 Similar data were reported for each of the examined zoos and $71.7 \%$ of the examined animals which 270 died due to infective agents were ruminants.

271 According to scientific literature; ruminants frequently die from infectious diseases, mostly 272 related to their intestinal flora swing. 
273 Links between diet and gastrointestinal problems have been reported (Zenker et al., 2009;

274 Schilcher et al., 2013; Taylor et al., 2013). Moreover, diet and lack of structured feed items can

275 be associated with acidosis in ruminants (Gattiker 2014).

276 Enteritis and other pathological conditions of the digestive system were not the only diseases to have

277 been identified, pulmonary diseases were also present. In fact, in every zoo (as described in Tables 5, 6

278 and 7), pneumonia and other pulmonary diseases were very common.

279 Respiratory infections are multifactorial diseases (Jubb et al., 2015). Climate change is likely to be one

280 of the factors which could increase the occurrence, distribution and prevalence of infectious diseases of

281 the lung (Mirsaeidi et al., 2015). This result also coincides with literature, in particular for livestock.

282 Different factors could affect livestock diseases when influenced by climate changes, such as the

283 virulence of the pathogen itself, presence of vectors (if any), farming practices and land use, zoological

284 and environmental factors and the establishment of new microenvironments and microclimates. The

285 interaction of these factors is an important consideration in forecasting how livestock diseases may be

286 spread (Gale et al., 2009).

287 In this study we also considered the mortality rate for each year. These data confirm that, even if there

288 are no trigger factors of an uncontrollable epidemic in a territory, a different animal species in different

289 years may be more prone to death.

290 Moreover, as demonstrated in this study, and also reported in a previous paper (Scaglione et al., 2010),

291 in white lion cubs an increased risk of inbreeding and genetic abnormalities can be a peculiar element

292 in zoos that are involved in the breeding of rare or endangered species, when genetic diversity can be

293 low in captive populations (Hoseyet al., 2009).

294 In Zoo 2, out of 48 dead carnivores, 14 (29.2\%) died from infectious diseases and 15 (31.2\%) died

295 from genetic diseases or malformations. These latest findings, due to inbreeding, arose in felines, and 
296 in particular in the cubs. As described in the introduction, the use of studbooks may limit inbreeding

297 and the consequent genetic abnormalities occurring in zoo animals (Leipold, 1980).

298 In literature different studies have been conducted on animal necropsies and they normally focus on a 299 single animal species (EAZWV; 2008; Joyce-Zuniga et al., 2014).

300 A holistic approach was carried out in 1983, by the San Diego Zoo and the Department of Pathology of 301 Zoo Animals, which conducted a survey on zoo animal necropsies over a fourteen-year period (Griner, 302 1983). Necropsies of wildlife and zoo animals were performed, taking into account all the species and 303 all the taxa. The veterinarians highlighted the importance of necropsies and collection of data.

304 CONCLUSIONS

305 In conclusion, this research has been carried out to highlight how conservation, histology and 306 pathology are:

-all connected through individual animals; •extremely important to maintain populations of rare and endangered species and to learn more about their morphological and physiological conditions; -useful to control diseases, parasites and illnesses which could have a great impact on those captive species.

The necropsy room could represent an observatory on Zoo animal health. 
319

320

321

322

323

324

325

326

327

328

329

330

331

332

333

334

335

336

337

338

339

341
Gattiker C, Espie I, Kotze A, Lane EP, Codron D, Clauss M. 2014. Diet and diet-related disorders in captive ruminants at the national zoological gardens of South Africa. Zoo Biology 33(5):426-432. 
342 Griffin DR. 1992. Animal Minds, Chicago, IL; University of Chicago Press. 376 p.

343 Griner LA. 1983. Pathology of Zoo Animals: A Review of Necropsies Conducted over a Fourteen-Year

344 Period at the San DiegoWild Animal Park. Zoological Society of San Diego, San Diego

345 Hinshaw KC, Amand WB, Tinkelman CL. 1996. Preventive medicine. In: Kleiman DG, Allen ME,

346 Thompson KV, Lumpkin S. ed. Wild Mammals in Captivity: Principles and Technique. $1^{\text {st }}$ ed.

347 Chicago, IL: University of Chicago Press p.16-24.

348 Hosey GR, Melfi V, Pankhurst S. 2009. Zoo Animals: Behaviour, Management, and Welfare. $2^{\text {nd }}$ ed.

349 Oxford, UK: Oxford University Press. 688 p.

350 Hutchins M. 2001. Research: overview. In: Bell CE, ed. Encyclopedia of the World's Zoos. $1^{\text {st }}$ ed.

351 Chicago, IL: Fitzroy Dearborn p. 1076-1080.

352 IUDZG/CBSG (International Union of Directors of Zoological Gardens/ Conservation Breeding 353 Specialist Group), 1993. Executive Summary, The World Zoo Conservation Strategy; The Role of the 354 Zoos and Aquaria of the World in Global Conservation. Chicago Zoological Society, Brookfield, 355 Illinois, U.S.A. 14p.

356 Joyce-Zuniga NM, Roesler J, Andrus CH, Sutherland-Smith M, Rideout BA, Pye GW. 2014. 357 Gastrointestinal torsions and intussusceptions in northern koalas (Phascolarctoscinereus) at San Diego 358 Zoo (1976-2012). Journal of Zoo and Wildlife Medicine 45: 118-126.

359 Jubb KVE, Kennedy PC, Palmer NC. 2015.Ed. By M. Grant Maxi. Jubb, Kennedy and Palmer's 360 Pathology of Domestic Animals.6thEdition

361 Leipold HW. 1980. Congenital defects of zoo and wild mammals: a review. In: Montali RJ, Migaki G, 362 ed. The Comparative Pathology of Zoo Animals. Washington, Washington DC: Smithsonian 363 Institutionp. 457-470.

364 Mench JA. 1998. Why it is important to understand animal behavior. ILAR Journal 39: 20-26. 
365 Mirsaeidi M, Motahari H, TaghizadehKhamesi M, Sharifi A, Campos M, Schraufnagel DE.

366 2016. Climate Change and Respiratory Infections. Annals of the American Thoracic

367 Society13(8):1223-1230.

368 Morgan KN, Tromborg CT. 2007. Sources of stress in captivityApplied Animal Behaviour

369 Science 102: 262-302.

370 Norton TM. 1993. Preventive medicine protocols for reintroduction programs. In: Proceeding of the

371 Annual Meeting of the American Association of Zoo Veterinarians. Philadelphia, USA: American

372 Association of Zoo Veterinarians p. 323-332.

373 Robinson MH. 1989. The zoo that is not: education for conservation. ConservationBiology3: 213-215.

374 Ryder OA, Feistner ATC. 1995. Research in zoos; a growth area in conservation. Biodiversity and

375 Conservation, 4: 671-677

376 Salas M, Temple D, Abáigar T, Cuadrado M, Delclaux M, Enseñat C, Almagro V, Martínez-

377 Nevado E, Quevedo MÁ, Carbajal A, Tallo-Parra O, Sabés-Alsina M, Amat M, Lopez-Bejar M,

378 Fernández-Bellon H, Manteca X. 2016. Aggressive behavior and hair cortisol levels in captive

379 Dorcas gazelles (Gazelladorcas) as animal-based welfare indicators. Zoo Biology 35(6):467-473.

380 Scaglione FE, Schröder C, Degiorgi G, Zeira O, Bollo E. 2010. Cranial malformations in related white

381 lions (Pantheraleokrugeri). Veterinary Pathology 47: 1095-1099.

382 Schaftenaar W. 2002. Use of vaccination against foot and mouth disease in zoo animals, 383 endangered species and exceptionally valuable animals.. Revue Scientifique Et Technique. 384 21(3):613-623. 
385 Schilcher B, Baumgartner K, Geyer H, Liesegang A. 2013. Investigations on rumen health of

386 different wild ruminants in relation to feeding management. Journal of zoo and aquarium 387 research $1: 28-30$.

388 Seeley KE, Garner MM, Waddell WT, Wolf KN. 2016. A survey of diseases in captive red 389 wolves (Canisrufus), 1997-2012. Journal of Zoo and Wildlife Medicine 47:83-90

390 Silberman MS. 1988. Compendium of Occupational Health \& Safety Programs (Laboratory \& 391 Zoological Institutions). R.W. Woodruff Health Sci. Ctr. Emory Univ. Atlanta, GA. Guidelines 392 of Zoo and Aquarium veterinary medical programs and veterinary hospitals.

393 StrongVJ, GrindlayD, Redrobe S, Cobb M, White K. 2016. A systematic review of the literature 394 relating to captive great ape morbidity and mortality Journal of Zoo and Wildlife Medicine 395 47(3):697-710.

396 Taylor LA, Schwitzer C, Owen-Smith N, Kreuzer M, Clauss M. 2013. Feeding practices for 397 captive greater kudus (Tragelaphusstrepsiceros) in UK collections as compared to diets of 398 free-ranging specimens. Journal of zoo and aquarium research 1:7-13.

399 Vaz J, Narayan EJ, Dileep Kumar R, Thenmozhi K, Thiyagesan K, Baskaran N. 2017. Prevalence and 400 determinants of stereotypic behaviours and physiological stress among tigers and leopards in Indian 401 zoos. PLoS One 12(4):e0174711.

402 WAZA (World Association of Zoos and Aquariums). 2005. Building a Future for Wildlife: The World 403 Zoo and Aquarium Conservation Strategy, Liebelfeld-Berne.

404 WAZA (World Association of Zoos and Aquariums). 2009. Turning the Tide: A Global Aquarium 405 Strategy for Conservation and Sustainability, Liebelfeld-Berne

406 WRI/IUCN/UNEP/FAO/UNESCO (World Resources Institute/The World Conservation Union/United 407 Nations Environment Programme in consultation with the Food and Agriculture Organization and the 
408 United Nations Education, Scientific and Cultural organization) 1992. Global Biodiversity Strategy:

409 Guidelines for Action to Save, Study and Use Earth's Biotic Wealth Sustainably and Equitably.

410 Washington, Washington DC: WRI.

411 Zenker W, Clauss M, Huber J, Altenbrunner-Martinek B. 2009. Rumen pH and hoof health in

412 two groups of captive wild ruminants. In: Clauss M, Fidgett A, Hatt J-M, Huisman T, Hummel

413 J., Nijboer J., Plowman A. editors. Zoo animal nutrition IV. Fürth, Germany: FilanderVerlag: p $414 \quad 247-254$.

415 Zhang H, Shan F, Zhou X, Li B, Zhai JQ, Zou SZ, Wu MF, Chen W, Zhai SL, Luo ML. 2017.

416 Outbreak and genotyping of canine distemper virus in captive Siberian tigers and red pandas.

417 Scientific Reports 7(1):8132. 


\section{Table $\mathbf{1}$ (on next page)}

total number of dead animals and their causes of death in the three different zoo

Animals are classified according to their digestive system, with reference to the three zoos 


\begin{tabular}{|c|c|c|c|c|c|c|c|c|c|c|c|c|c|}
\hline & \multicolumn{3}{|c|}{ Monogastric herbivores } & \multicolumn{3}{|c|}{ Ruminants } & \multicolumn{3}{|c|}{ Carnivores } & \multicolumn{3}{|c|}{ Omnivores } & \multirow[t]{2}{*}{ TOTAL } \\
\hline & 2001 & 2002 & 2003 & zoo 1 & zoo 2 & 2003 & zoo 1 & 2002 & zoo 3 & zoo 1 & zoo 2 & 2003 & \\
\hline $\begin{array}{l}\text { Infect. } \\
\text { diseases }\end{array}$ & 19 & 1 & 11 & 22 & 75 & 30 & 1 & 14 & 2 & 1 & 1 & & 177 \\
\hline Traumas & 5 & 3 & 2 & 6 & 17 & 6 & 1 & 4 & 1 & & 1 & 1 & 47 \\
\hline Complications & & 1 & & 2 & 9 & 1 & & 5 & & & 2 & & 20 \\
\hline $\begin{array}{l}\text { Genetic } \\
\text { diseases and } \\
\text { malformations }\end{array}$ & & & & & & & & 15 & & & & & 15 \\
\hline Other & 1 & & 2 & 1 & 4 & 2 & & 10 & 1 & 1 & & 1 & 23 \\
\hline Tot. & 25 & 5 & 15 & 31 & 105 & 39 & 2 & 48 & 4 & 2 & 4 & 2 & 282 \\
\hline
\end{tabular}

1 


\section{Table 2 (on next page)}

mortality in Zoo 1 from 2005 to 2015

Animals are classified according to their digestive system, year and cause of mortality 


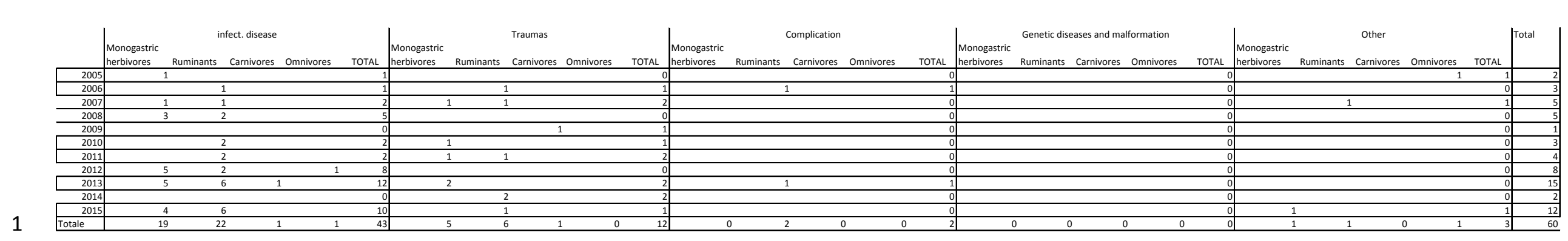




\section{Table 3(on next page)}

mortality in Zoo 2 from 2004 to 2014

Animals are classified according to their digestive system, year and cause of mortality 


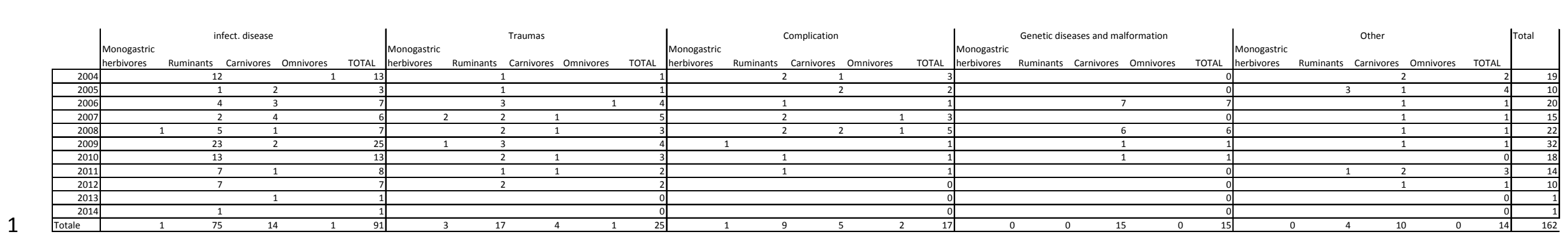




\section{Table 4 (on next page)}

mortality in Zoo 3 from 2004 to 2006

Animals are classified according to their digestive system, year and cause of mortality 


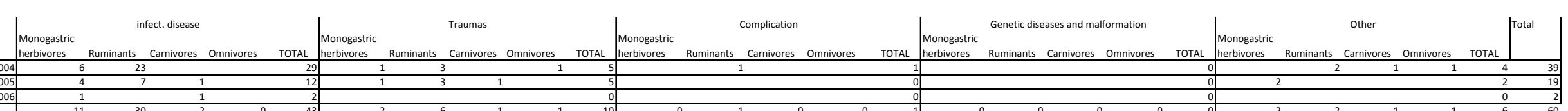

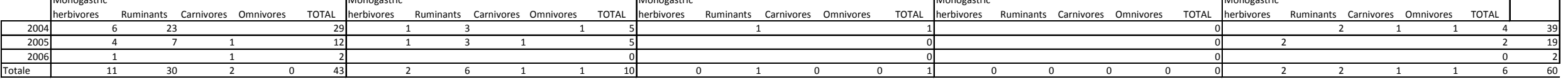




\section{Table 5 (on next page)}

results obtained from laboratory investigations performed on animal death in the zoo 1 


\begin{tabular}{|c|c|c|c|c|}
\hline $\begin{array}{c}\text { Registernumber } \\
1 \mathrm{~A}\end{array}$ & $\begin{array}{l}\text { Year } \\
2005\end{array}$ & $\begin{array}{l}\text { Specie } \\
\text { Horse }\end{array}$ & $\begin{array}{l}\text { Causes of death } \\
\text { Septicemia }\end{array}$ & $\begin{array}{c}\text { Lab. findings } \\
\text { C. perfrigens type } \\
\text { D }\end{array}$ \\
\hline $2 \mathrm{~A}$ & 2005 & Skunk & $\begin{array}{l}\text { Pulmonary } \\
\text { emphysema }\end{array}$ & - \\
\hline $3 \mathrm{~A}$ & 2006 & Fallow deer & Trauma & - \\
\hline $4 \mathrm{~A}$ & 2006 & Fallow deer & Toxemia syndrome & - \\
\hline $5 \mathrm{~A}$ & 2006 & Ilama & Pneumonia & - \\
\hline $6 \mathrm{~A}$ & 2007 & Goat & Aspiration pneumonia & - \\
\hline $7 \mathrm{~A}$ & 2007 & Grey squirrel & Trauma & - \\
\hline $8 \mathrm{~A}$ & 2007 & Deer & Trauma & - \\
\hline $9 \mathrm{~A}$ & 2007 & Goat & Pneumonia & \\
\hline $10 \mathrm{~A}$ & 2007 & Patagonia hare & Septicemia & Pseudotuberculosis \\
\hline $11 \mathrm{~A}$ & 2008 & Ilama & Pneumonia & - \\
\hline $12 \mathrm{~A}$ & 2008 & Ilama & Pneumonia & - \\
\hline $15 \mathrm{a}$ & 2008 & Patagonia hare & Septicemia & - \\
\hline $13 \mathrm{~A}-14 \mathrm{~A}$ & 2008 & $\begin{array}{c}\text { Domestic } \\
\text { rabbits }\end{array}$ & Pneumonia & - \\
\hline $16 \mathrm{~A}$ & 2009 & Siberian tiger & Internal hemorrhage & - \\
\hline $17 \mathrm{~A}$ & 2010 & Tibetan goat & $\begin{array}{c}\text { Clostridial } \\
\text { enterocolitis }\end{array}$ & Clostridiosis \\
\hline $18 \mathrm{~A}$ & 2010 & Hare & Trauma & \\
\hline $19 \mathrm{~A}$ & 2010 & Tibetan goat & Septicemia & E. coli \\
\hline $20 \mathrm{~A}$ & 2011 & Ilama & Septicemia & Salmonellosis \\
\hline $21 \mathrm{~A}$ & 2011 & Antelope & Pleuritis & - \\
\hline $22 \mathrm{~A}$ & 2012 & Antelope & Septicemia & - \\
\hline $23 \mathrm{~A}$ & 2012 & Deer & Cranial trauma & - \\
\hline $24 \mathrm{~A}$ & 2012 & Deer & Septicemia & Actinobacillosis \\
\hline $25 \mathrm{~A}$ & 2012 & Hare & Trauma & - \\
\hline $26 \mathrm{~A}$ & 2012 & Swine & Pericarditis & - \\
\hline $27-31 \mathrm{~A}$ & 2012 & Hares & Pneumonia & - \\
\hline $32 \mathrm{~A}$ & 2013 & Deer & Septicemia & Enterococcus \\
\hline $33 \mathrm{~A}$ & 2013 & Ilama calf & Pneumonia & - \\
\hline $34-35 \mathrm{~A}$ & 2013 & Eulemurs & Trauma & - \\
\hline $36 \mathrm{~A}$ & 2013 & Hare & Septicemia & Pasteurella \\
\hline
\end{tabular}




\begin{tabular}{|c|c|c|c|c|}
\hline & & & & multocida \\
\hline $37-40 \mathrm{~A}$ & 2013 & Rabbits & Pneumonia & - \\
\hline $41 \mathrm{~A}$ & 2013 & Siberian tiger & $\begin{array}{l}\text { Pulmonary } \\
\text { hemorrhage }\end{array}$ & - \\
\hline $42-43 A$ & 2013 & Mohr gazelles & Pneumonia & - \\
\hline $44 \mathrm{~A}$ & 2013 & $\begin{array}{c}\text { Thompson } \\
\text { gazelle }\end{array}$ & Dystocia & - \\
\hline $45-46 \mathrm{~A}$ & 2013 & Deer & Pneumonia & - \\
\hline $47-48 \mathrm{~A}$ & 2014 & Mohr gazelle & Trauma & - \\
\hline $49 \mathrm{~A}$ & 2015 & Horse & Liver failure & - \\
\hline $50-51 \mathrm{~A}$ & 2015 & $\begin{array}{c}\text { Thompson } \\
\text { gazelle }\end{array}$ & Septicemia & - \\
\hline $52 \mathrm{~A}$ & 2015 & Watusi & Enteritis & - \\
\hline $53 \mathrm{~A}$ & 2015 & Gazelle & Pneumonia & - \\
\hline $54 \mathrm{~A}$ & 2015 & Yak & Pneumonia & - \\
\hline $55 \mathrm{~A}$ & 2015 & Goat & Trauma & - \\
\hline $56 \mathrm{~A}$ & 2015 & Goat & Pneumonia & - \\
\hline $57-60 \mathrm{~A}$ & 2015 & Rabbit & Pneumonia & \\
\hline
\end{tabular}




\section{Table 6(on next page)}

results obtained from laboratory investigations performed on animal death in the zoo 2 


\begin{tabular}{|c|c|c|c|c|}
\hline Data & Years & Species & Causes of death & Lab. findings \\
\hline 1B & 2004 & Lion & Neoplasia & Alveolar Carcinoma \\
\hline $2 \mathrm{~B}$ & 2004 & Opossum & Encephalitis & - \\
\hline 3B & 2004 & Goat & Pneumonia & - \\
\hline 4B & 2004 & Dromedary & Enteritis & - \\
\hline $5 \mathrm{~B}$ & 2004 & Antelope & Blood poisoning & - \\
\hline $6 \mathrm{~B}$ & 2004 & Goat & Pneumonia & - \\
\hline $7 \mathrm{~B}$ & 2004 & Antelope & Pneumonia & - \\
\hline $8 \mathrm{~B}$ & 2004 & Yak & Clostridiosis & $\begin{array}{l}\text { Clostridium spp. } \\
\text { E. coli }\end{array}$ \\
\hline 9B & 2004 & Ilama & Thoracic Trauma & - \\
\hline 10B & 2004 & Nilgai & Clostridiosis & $\begin{array}{l}\text { Clostridium } \\
\text { perfringens }\end{array}$ \\
\hline 11B & 2004 & Watusi & $\begin{array}{c}\text { Chronic gastritis and } \\
\text { entheritis }\end{array}$ & - \\
\hline $12 \mathrm{~B}$ & 2004 & Dromedary & Septic granuloma & $\begin{array}{l}\text { Trichostrongylus spp } \\
\text { Protostrongylus spp. } \\
\text { Nematodirus spp. }\end{array}$ \\
\hline 13B & 2004 & Blesbuck & Pneumonia and pleuritis & $\begin{array}{l}\text { Trichostrongylus spp. } \\
\text { Protostrongylus spp. } \\
\text { Ostertagia spp. }\end{array}$ \\
\hline 14B & 2004 & Eland & Blood poisoning & - \\
\hline 15B & 2004 & Eland & Pneumonia & E. coli \\
\hline 16B & 2004 & Lion & Paraplegia (euthanasia) & - \\
\hline 17B & 2004 & Blesbuck & Pneumonia and pleuritis & - \\
\hline 18B & 2004 & Goat & Pneumonia & \\
\hline 19B & 2004 & Lion & Aspiration pneumonia & - \\
\hline 20B & 2005 & Giraffe & Heart attack & - \\
\hline 21B & 2005 & Goat & Not determined & - \\
\hline $22 \mathrm{~B}$ & 2005 & Goat & Not determined & - \\
\hline $23 \mathrm{~B}$ & 2005 & White Lion & Aspiration pneumonia & - \\
\hline
\end{tabular}




\begin{tabular}{|c|c|c|c|c|}
\hline 24B & 2005 & Lion & Neonatal mortality & - \\
\hline $25 \mathrm{~B}$ & 2005 & Lion & Mesothelioma & - \\
\hline 26B & 2005 & White lion & Pneumonia & - \\
\hline 27B & 2005 & Antelope & Severe pneumonia & - \\
\hline $28 \mathrm{~B}$ & 2005 & Tiger & Peritonitis & - \\
\hline 29B & 2005 & Barbary sheep & Trauma & - \\
\hline $30 \mathrm{~B}$ & 2006 & Tiger & Enteritis & - \\
\hline 31B & 2006 & Racoon & $\begin{array}{l}\text { Trauma (thoracic } \\
\text { hemorrage) }\end{array}$ & - \\
\hline $32 \mathrm{~B}$ & 2006 & Tiger & Not determined & - \\
\hline $33 \mathrm{~B}$ & 2006 & White lion & Inborn malformation & - \\
\hline $34 \mathrm{~B}$ & 2006 & Mouflon & Trauma & - \\
\hline $35 \mathrm{~B}$ & 2006 & Lion & Maxillary hypoplasia & - \\
\hline $36 \mathrm{~B}$ & 2006 & White Lion & Neonatal mortality & - \\
\hline 37B & 2006 & White Lion & Neonatal mortality & - \\
\hline $38 \mathrm{~B}$ & 2006 & White Lion & Neonatal mortality & - \\
\hline 39B & 2006 & White Lion & Neonatal mortality & - \\
\hline $40 \mathrm{~B}$ & 2006 & Waterbuck & Politrauma & - \\
\hline 41B & 2006 & Goat & Pneumonia & - \\
\hline $42 \mathrm{~B}$ & 2006 & Waterbuck & Foreign body (peritonitis) & - \\
\hline $43 \mathrm{~B}$ & 2006 & Siberian Tiger & Severe pneumonia & - \\
\hline $44 \mathrm{~B}$ & 2006 & Gemsbuck (Oryx) & Pneumonia & - \\
\hline $45 \mathrm{~B}$ & 2006 & Waterbuck & Severe pneumonia & - \\
\hline $46 \mathrm{~B}$ & 2006 & Eland & Trauma & - \\
\hline $47 \mathrm{~B}$ & 2006 & White lion & Neonatal mortality & - \\
\hline $48 \mathrm{~B}$ & 2006 & White lion & Severe pneumonia & - \\
\hline 49B & 2007 & Siberian Tiger & Severe pneumonia & - \\
\hline $50 \mathrm{~B}$ & 2007 & Eland & Severe pneumonia & - \\
\hline $51 \mathrm{~B}$ & 2007 & Racoon & Poisoning & - \\
\hline $52 \mathrm{~B}$ & 2007 & Hippopotamus & Trauma & - \\
\hline $53 \mathrm{~B}$ & 2007 & Wildebeest & Trauma & - \\
\hline $54 \mathrm{~B}$ & 2007 & Dromedary & Abortion & E. colt \\
\hline
\end{tabular}




\begin{tabular}{|c|c|c|c|c|}
\hline $55 \mathrm{~B}$ & 2007 & Gemsbuck (Oryx) & Trauma & - \\
\hline $56 \mathrm{~B}$ & 2007 & Lion & Pneumonia & - \\
\hline $57 \mathrm{~B}$ & 2007 & Tiger & Cranial trauma & - \\
\hline $58 \mathrm{~B}$ & 2007 & Tiger & Suffocation & - \\
\hline $59 \mathrm{~B}$ & 2007 & Tiger & Severe pneumonia & - \\
\hline $60 \mathrm{~B}$ & 2007 & Siberian Tiger & $\begin{array}{l}\text { Severe rhinitis and } \\
\text { pneumonia }\end{array}$ & - \\
\hline $61 \mathrm{~B}$ & 2007 & Gemsbuck (Oryx) & Infection & Moraxella spp. \\
\hline $62 \mathrm{~B}$ & 2007 & Hippopotamus & Trauma & - \\
\hline $63 \mathrm{~B}$ & 2007 & Buffalo & Blood poisoning & - \\
\hline $64 B$ & 2008 & Lion & Trauma & - \\
\hline $65 \mathrm{~B}$ & 2008 & Deer & Trauma & - \\
\hline $66 \mathrm{~B}$ & 2008 & Tiger & Internal hemmorage & - \\
\hline $67 \mathrm{~B}$ & 2008 & Baboon hamadryad & Hypothermia & - \\
\hline $68 \mathrm{~B}$ & 2008 & Buffalo & Septicemia & - \\
\hline $69 B$ & 2008 & White lion & Pneumonia & - \\
\hline $70 \mathrm{~B}$ & 2008 & Waterbuck & Hypothermia & - \\
\hline $71 \mathrm{~B}$ & 2008 & Gemsbuck (Oryx) & Septicemia & - \\
\hline 72 & 2008 & White Lion & Neonatal mortality & - \\
\hline $73 \mathrm{~B}$ & 2008 & White Lion & Neonatal mortality & - \\
\hline $74 \mathrm{~B}$ & 2008 & White Lion & Neonatal mortality & - \\
\hline $75 \mathrm{~B}$ & 2008 & Eland & Pneumonia & - \\
\hline $76 \mathrm{~B}$ & 2008 & Barbary sheep & Trauma & - \\
\hline $77 \mathrm{~B}$ & 2008 & Lion & Aspiration pneumonia & - \\
\hline $78 \mathrm{~B}$ & 2008 & Lion & Aspiration pneumonia & - \\
\hline $79 B$ & 2008 & Goat & Pneumonia & - \\
\hline $80 \mathrm{~B}$ & 2008 & Patagonian hare & Enteritis & - \\
\hline $81 \mathrm{~B}$ & 2008 & Lion & Neonatal mortality & - \\
\hline $82 \mathrm{~B}$ & 2008 & Lion & Neonatal mortality & - \\
\hline $83 \mathrm{~B}$ & 2008 & Lion & Neonatal mortality & - \\
\hline $84 \mathrm{~B}$ & 2008 & Eland & Severe septicemia & - \\
\hline $85 \mathrm{~B}$ & 2008 & Gemsbuck (Oryx) & Neonatal mortality & - \\
\hline $86 \mathrm{~B}$ & 2009 & Eland & Abdominal trauma & - \\
\hline $87 \mathrm{~B}$ & 2009 & Waterbuck & Pneumonia & E. coli \\
\hline
\end{tabular}




\begin{tabular}{|c|c|c|c|c|}
\hline $88 \mathrm{~B}$ & 2009 & Waterbuck & Trauma & - \\
\hline $89 \mathrm{~B}$ & 2009 & Waterbuck & Enteritis & E. coli \\
\hline $90 \mathrm{~B}$ & 2009 & Goat & Lymphoadenitis & - \\
\hline $91 \mathrm{~B}$ & 2009 & Goat & Enteritis and pneumonia & $\begin{array}{c}\text { Staphylococcus xylosus } \\
\text { Streptococcus bovis } \\
\text { E. coli } \\
\text { C. perfringens }\end{array}$ \\
\hline $92 \mathrm{~B}$ & 2009 & Goat & Enteritis & - \\
\hline 93B & 2009 & Waterbuck & Peritonitis & - \\
\hline 94B & 2009 & Waterbuck & Trauma & - \\
\hline $95 \mathrm{~B}$ & 2009 & Waterbuck & Metritis & $\begin{array}{c}\text { E.coli } \\
\text { Streptococcus bovis }\end{array}$ \\
\hline $96 \mathrm{~B}$ & 2009 & Tiger & Pulmonary abscess & - \\
\hline 97B & 2009 & Tiger & Chronic nephritis & - \\
\hline 98B & 2009 & Barbary sheep & Enteritis & $\begin{array}{c}\text { Salmonella } \\
\text { venezuelana }\end{array}$ \\
\hline 99B & 2009 & Goat & Pneumonia & - \\
\hline $100 \mathrm{~B}$ & 2009 & Hippopotamus & Trauma & - \\
\hline 101B & 2009 & Barbary sheep & Septicemia & - \\
\hline 102B & 2009 & Barbary sheep & Enteritis & - \\
\hline $103 \mathrm{~B}$ & 2009 & Tibetan Goat & Enteritis & - \\
\hline 104B & 2009 & Barbary sheep & Enteritis & - \\
\hline 105B & 2009 & Barbary sheep & Enteritis & - \\
\hline $106 \mathrm{~B}$ & 2009 & Ilama & Enteritis & E. coli \\
\hline 107B & 2009 & Dromedary & Abortion & - \\
\hline 108B & 2009 & Lion & Neonatal mortality & \\
\hline 109B & 2009 & Barbary sheep & Deterioration & - \\
\hline 110B & 2009 & White lion & $\begin{array}{l}\text { Inborn disease } \\
\text { (macroglossia) }\end{array}$ & - \\
\hline 111B & 2009 & Barbary sheep calf & Enteritis and pneumonia & - \\
\hline $112 \mathrm{~B}$ & 2009 & Barbary sheep & Pneumonia & - \\
\hline $113 \mathrm{~B}$ & 2009 & Barbary sheep & Enteritis & - \\
\hline $114 \mathrm{~B}$ & 2009 & Goat & Pneumonia & - \\
\hline 115B & 2009 & White donkey & Colic & - \\
\hline $116 \mathrm{~B}$ & 2009 & Wildebeest & Hemorragic peritonitis & - \\
\hline 117B & 2009 & Cameroon Goat & Abortion & - \\
\hline $118 \mathrm{~B}$ & 2010 & Watusi & Pneumonia & - \\
\hline 119B & 2010 & Siberian tiger & Trauma & Diaphragmatic hernia \\
\hline $120 \mathrm{~B}$ & 2010 & Waterbuck & Pneumonia & - \\
\hline $121 \mathrm{~B}$ & 2010 & Goat & Pulmonary congestion & - \\
\hline
\end{tabular}




\begin{tabular}{|c|c|c|c|c|}
\hline $122 B$ & 2010 & Goat & Pulmonary congestion & - \\
\hline $123 \mathrm{~B}$ & 2010 & Gemsbuck (Oryx) & Anesthesia & - \\
\hline $124 \mathrm{~B}$ & 2010 & Sheep & Pulmonary congestion & - \\
\hline $125 \mathrm{~B}$ & 2010 & Goat & Pericardial effusion & - \\
\hline $126 B$ & 2010 & Gemsbuck (Oryx) & $\begin{array}{l}\text { Parasitic hepatitis and } \\
\text { pneumonia }\end{array}$ & - \\
\hline $127 \mathrm{~B}$ & 2010 & Waterbuck calf & Neonatal mortality & - \\
\hline $128 \mathrm{~B}$ & 2010 & Barbary sheep & Trauma & - \\
\hline 129B & 2010 & Siberian tiger & Fallot pentalogy & - \\
\hline $130 \mathrm{~B}$ & 2010 & Antelope & Hepatitis & - \\
\hline 131B & 2010 & Gemsbuck (Oryx) & Euthanasia & Septicemia \\
\hline 132B & 2010 & Waterbuck & Trauma & - \\
\hline 133B & 2010 & Waterbuck & Septicemia & - \\
\hline 134B & 2010 & Waterbuck & Septicemia & - \\
\hline $135 \mathrm{~B}$ & 2010 & Tibetan goat & Pericardial effusion & - \\
\hline $136 \mathrm{~B}$ & 2011 & Siberian tiger & Euthanasia & - \\
\hline 137B & 2011 & Wildebeest calf & Mesenteric hemorrage & - \\
\hline $138 \mathrm{~B}$ & 2011 & Dromedary & Neonatal mortality & - \\
\hline 139B & 2011 & Siberian tiger & Trauma & - \\
\hline 140B & 2011 & Eland & Septicemia & - \\
\hline 141B & 2011 & Gesmbuck & Trauma and septicemia & - \\
\hline 142B & 2011 & Antelope & Not determined & - \\
\hline 143B & 2011 & Gemsbuck & Pneumonia & - \\
\hline 144B & 2011 & Siberian tiger & Abortion and septicemia & - \\
\hline 145B & 2011 & Dromedary & $\begin{array}{c}\text { Pulmonary congestion and } \\
\text { septicemia }\end{array}$ & - \\
\hline $146 B$ & 2011 & Eland & Gastritis & - \\
\hline 147B & 2006 & Eland & Enteritis & - \\
\hline 148B & 2011 & Goat & Pulmonary edema & - \\
\hline 149B & 2011 & Tiger & Not determined & - \\
\hline $150 \mathrm{~B}$ & 2011 & Antelope & Mycosis & - \\
\hline $151 \mathrm{~B}$ & 2012 & Waterbuck & Septicemia & - \\
\hline $152 \mathrm{~B}$ & 2012 & Waterbuck & Trauma & - \\
\hline 153B & 2012 & Giraffe & Septicemia & $\begin{array}{c}\text { Achromobacter } \\
\text { xylosoxidans } \\
\text { Streptococcus bovis } \\
\text { Stenotrophomonas } \\
\text { maltophila }\end{array}$ \\
\hline $154 \mathrm{~B}$ & 2012 & Cow & Septicemia & - \\
\hline
\end{tabular}




\begin{tabular}{|c|c|c|c|c|}
\hline 155B & 2012 & Bison & Enteritis & - \\
\hline 156B & 2012 & Cameroon goat & Enteritis & - \\
\hline 157B & 2012 & Goat & Trauma & - \\
\hline 158B & 2012 & Gemsbuck & Degradation & - \\
\hline 159B & 2012 & Goat & Pneumonia & Pancreatic neoplasia \\
\hline 160B & 2012 & Cheetah & Neoplasia & - \\
\hline 161B & 2013 & Cheetah & Interstitial nephritis & - \\
\hline 162B & 2014 & Giraffe & Pericarditis &
\end{tabular}

1 


\section{Table 7 (on next page)}

results obtained from laboratory investigations performed on animal death in the zoo 3 


\begin{tabular}{|c|c|c|c|c|}
\hline Registernumber & Years & Species & Causes of death & Lab. findings \\
\hline $1 \mathrm{C}$ & 2004 & Barbary sheep & Pulmunary embolism & - \\
\hline $2 \mathrm{C}$ & 2004 & Ferret & Cirrhosis & - \\
\hline $3 \mathrm{C}$ & 2004 & Kangaroo & Pneumonia & - \\
\hline $4 \mathrm{C}$ & 2004 & Tibetan goat & Pneumonia & - \\
\hline $5 \mathrm{C}$ & 2004 & Cameroon sheep & Cysticercosis & Taenia saginata \\
\hline $6 \mathrm{C}$ & 2004 & Tibetan goat & Pneumonia & - \\
\hline $7 \mathrm{C}$ & 2004 & Barbary sheep calf & Trauma & - \\
\hline $8 \mathrm{C}$ & 2004 & Ilama & $\begin{array}{c}\text { Pneumonia and } \\
\text { pericarditis }\end{array}$ & - \\
\hline $9 \mathrm{C}$ & 2004 & Kangaroo & Pneumonia & - \\
\hline $10 \mathrm{C}$ & 2004 & Kangaroo & Liver disease & - \\
\hline $11 \mathrm{C}$ & 2004 & Kangaroo & Pneumonia & - \\
\hline $12 \mathrm{C}$ & 2004 & $\begin{array}{l}\text { Crab-eating } \\
\text { macaque }\end{array}$ & Liver failure & - \\
\hline $13 \mathrm{C}$ & 2004 & Fallow deer & Pneumonia & - \\
\hline $14 \mathrm{C}$ & 2004 & Fallow deer & Pneumonia & - \\
\hline $15 \mathrm{C}$ & 2004 & Girgentana goat & Pneumonia & - \\
\hline $16 \mathrm{C}$ & 2004 & Blackbuck & Pneumonia & - \\
\hline $17 \mathrm{C}$ & 2004 & Fallow deer calf & Trauma & - \\
\hline $18 \mathrm{C}$ & 2004 & Raccoon & Trauma & - \\
\hline $19 \mathrm{C}$ & 2004 & Barbary sheep & Pneumonia & - \\
\hline $20 \mathrm{C}$ & 2004 & Blackbuck & Pneumonia & - \\
\hline $21 \mathrm{C}$ & 2004 & Tibetan goat & Pneumonia & - \\
\hline $22 \mathrm{C}$ & 2004 & Barbary sheep calf & Trauma & - \\
\hline $23 \mathrm{C}$ & 2004 & Tibetan goat & Pulmonary edema & - \\
\hline $24 \mathrm{C}$ & 2004 & Goat & Pneumonia & - \\
\hline $25 \mathrm{C}$ & 2004 & Barbary sheep & Steatosis & - \\
\hline $26 \mathrm{C}$ & 2004 & Chital & Pneumonia & - \\
\hline $27 \mathrm{C}$ & 2004 & Barbary sheep calf & $\begin{array}{l}\text { Hemorrhagic } \\
\text { enteritis }\end{array}$ & - \\
\hline $28-29 C$ & 2004 & Barbary sheep & Pneumonia & - \\
\hline $30-32 \mathrm{C}$ & 2004 & Kangaroo & Pulmonary edema & - \\
\hline $33 \mathrm{C}$ & 2004 & Fallow deer & Predation & - \\
\hline $34 \mathrm{C}$ & 2004 & Angora Goat & Septicemia & - \\
\hline $35 \mathrm{C}$ & 2004 & Blackbuck & Pneumonia & - \\
\hline $36 \mathrm{C}$ & 2004 & Barbary sheep calf & Pneumonia & - \\
\hline $37-39 \mathrm{C}$ & 2004 & Tibetan goat & Pneumonia & - \\
\hline
\end{tabular}




\begin{tabular}{|c|c|c|c|c|}
\hline $40 \mathrm{C}$ & 2005 & Wallaby & Pulmonary edema & - \\
\hline $41 \mathrm{C}$ & 2005 & Wallaby & Septicemia & - \\
\hline $42 \mathrm{C}$ & 2005 & Squirrel & Trauma & - \\
\hline $43 \mathrm{C}$ & 2005 & Ferret & Trauma & - \\
\hline $44 \mathrm{C}$ & 2005 & Prairie dog & Hepatic neoplasia & - \\
\hline $45 \mathrm{C}$ & 2005 & Squirrel & Pneumonia & - \\
\hline $46 \mathrm{C}$ & 2005 & Ferret & $\begin{array}{c}\text { Hemorrhagic } \\
\text { enteritis }\end{array}$ & - \\
\hline $47 \mathrm{C}$ & 2005 & Antelope & Pneumonia & - \\
\hline $48 \mathrm{C}$ & 2005 & Barbary sheep & Trauma & - \\
\hline $49 \mathrm{C}$ & 2005 & Tibetan goat & $\begin{array}{l}\text { Pneumonia and } \\
\text { pleuritis }\end{array}$ & - \\
\hline $50 \mathrm{C}$ & 2005 & Kangaroo & $\begin{array}{c}\text { Pericardial effusion } \\
\text { and septicemia }\end{array}$ & - \\
\hline $51 \mathrm{C}$ & 2005 & Kangaroo & Steatosis & - \\
\hline $52 \mathrm{C}$ & 2005 & Barbary sheep & Pneumonia & - \\
\hline $53 \mathrm{C}$ & 2005 & Goat & Trauma & - \\
\hline $54 \mathrm{C}$ & 2005 & Angora goat & Pericardial effusion & \\
\hline $55 \mathrm{C}$ & 2005 & Fallow deer & Pneumonia & - \\
\hline $56 \mathrm{C}$ & 2005 & Antelope & Peritonitis & - \\
\hline $57 \mathrm{C}$ & 2005 & Dwarf goat & Trauma & - \\
\hline $58 \mathrm{C}$ & 2005 & Deer & Pneumonia & - \\
\hline $59 \mathrm{C}$ & 2006 & Blue monkey & $\begin{array}{l}\text { Pulmonary } \\
\text { emphysema }\end{array}$ & - \\
\hline $60 \mathrm{C}$ & 2006 & Fox & Pneumonia & - \\
\hline
\end{tabular}


Figure 1

Causes of death in the three different zoos

Dead animals classified according to their digestive system and their causes of death in the three different zoos

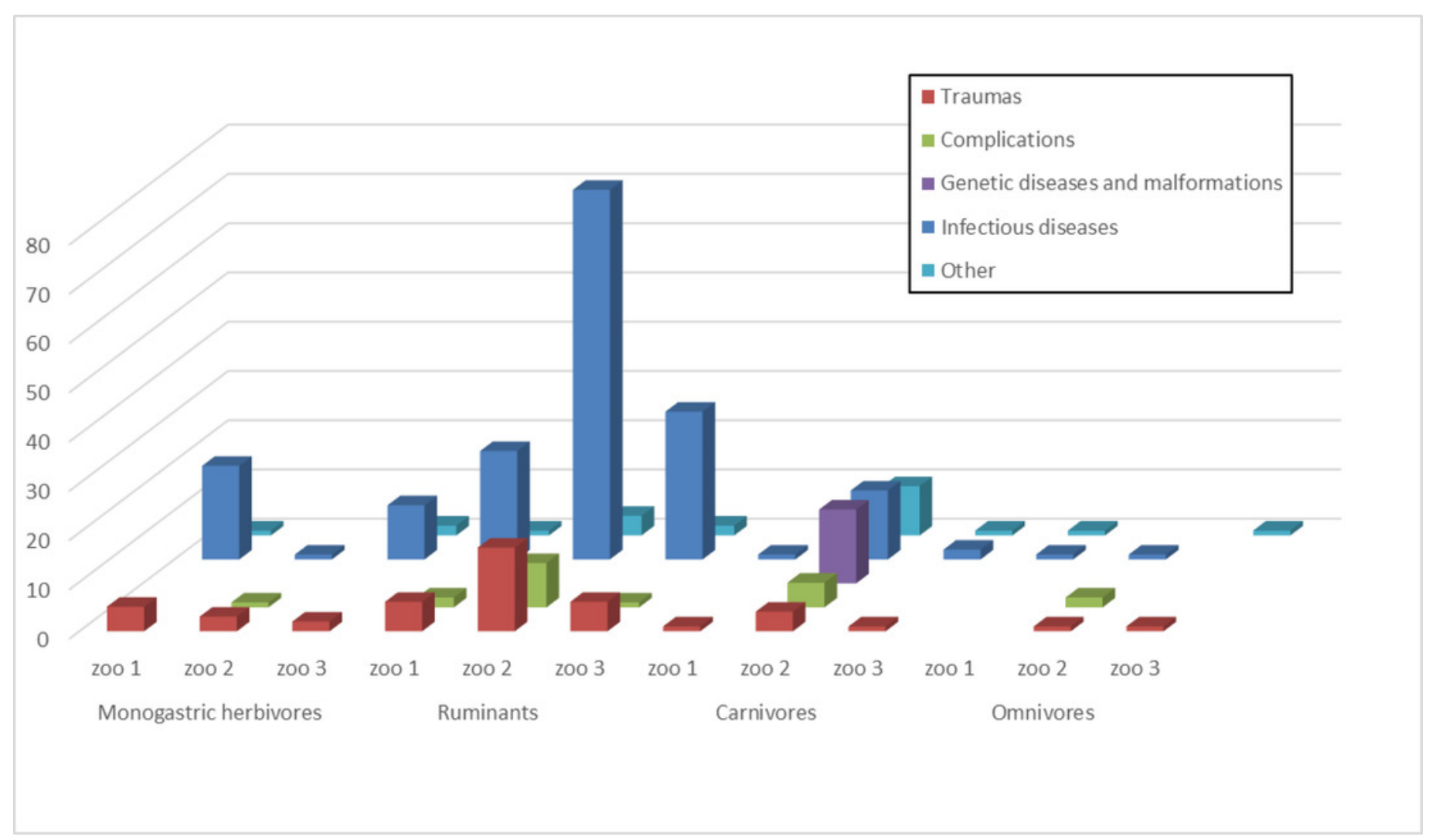

